\title{
KAJIAN KRITIS TERHADAP EKSISTENSI BANK TANAH DALAM UNDANG-UNDANG NO. 11 TAHUN 2020 TENTANG CIPTA KERJA
}

\section{CRITICAL ASSESSMENT OF THE EXISTENCE OF LAND BANKS IN LAW NUMBER 11 OF 2020 CONCERNING JOB CREATION}

\author{
Nizam Zakka Arrizal \\ Universitas PGRI Madiun \\ nizam@unipma.ac.id \\ Siti Wulandari \\ Universitas PGRI Madiun \\ dari8948@gmail.com
}

\begin{abstract}
Abstrak
Penelitian ini mengkaji tentang keberadaan Bank Tanah yang didirikan berdasarkan UndangUndang No. 11 Tahun 2020 Tentang Cipta Kerja dimana mendapatkan pro dan kontra dari masyarakat, aktivis, dan akademisi. Tanah sebagai karunia Tuhan Yang Maha Esa dikuasai oleh Negara dan dipergunakan sebesar-besarnya untuk kemakmuran rakyat. Isu hukum yang dibahas dalam penelitian ini adalah Urgensi pendirian bank tanah dan Peran serta fungsi Bank Tanah sebagai lembaga pengelola tanah. Metode yang digunakan adalah metode penelitian yuridis normatif, yaitu penelitian terhadap asas-asas hukum dengan menggunakan data sekunder. Metode analisis data yang digunakan adalah metode kualitatif dan alat pengumpulan data yang digunakan adalah studi dokumen. Hasil penelitian ini adalah kehadiran Bank tanah sangat dibutuhkan oleh masyarakat dan pemerintah dalam pengelolaan dan penataan tanah untuk kepentingan umum dan tempat tinggal. Peran dan fungsi Bank tanah adalah lembaga yang mengelola tanah dengan melaksanakan perencanaan, perolehan, pengadaan, pengelolaan, pemanfaatan, dan pendistribusian tanah.
\end{abstract}

Kata Kunci: Bank Tanah, Pertanahan, Undang-Undang Cipta Kerja

\begin{abstract}
This research examines the existence of a Land Bank which was established based on law number 11 of 2020 concerning Job Creation which gets the pros and cons of the community, activists, and academics. Land as a gift from God Almighty is controlled by the State and used as much as possible for the prosperity of the people. The legal issue discussed in this study is the urgency of establishing a land bank and the role and function of the Land Bank as a land management institution. The method used is a normative juridical research method, namely research on legal principles using secondary data. The data analysis method used was qualitative methods and the data collection tool used was document study. The result of this research is that the presence of a land bank is very much needed by the community and government in the management and arrangement of land for the public interest and residence. The role and function of a land bank is an institution that manages land by
\end{abstract}


carrying out the planning, acquisition, procurement, management, utilization and distribution of land

Keywords : Land Bank, Land, Job Creation Act.

\section{A. Pendahuluan}

Disahkannya Undang-Undang No 11 Tahun 2020 tentang Cipta Kerja pada 5 Oktober 2020 (selanjutnya disebut UU Cipta Kerja) menimbulkan pro dan kotra. Dari segala pro dan kontra tersebut, perlu kita cermati bersama tujuan disahkannya undang-undang itu dari perspektif hukum agraria. Menurut ketua Badan Legislasi DPR RI, ada beberapa poin penting yang diatur di dalam UU Cipta Kerja yang terkait Bank Tanah yaitu percepatan reformasi agraria, pemerintah akan mempercepat reformasi agraria dan redistribusi tanah yang akan dilakukan oleh Bank Tanah. ${ }^{1}$

Keberadaan Bank Tanah ini merupakan salah satu terobosan pemerintah dalam usahanya menyediakan tanah untuk kepentingan umum dan kepentingan masyarakat yang membutuhkan tanah. Khusus untuk kepentingan umum, keberadaan Bank Tanah akan sangat membantu pemerintah

\footnotetext{
${ }^{1}$ Supratman Andi Agtas, Laporan Badan Legislasi DPR RI Dalam Rangka Pembicaraan Tingkat II / Pengambilan Keputusan Hasil Pembahasan RUU tentang cipta kerja yang telah diselesaikan oleh Badan Legislasi Dalam Rapat Paripurna DPR RI, 6 Oktober 2020, hlm. 4.
}

untuk memperoleh tanah yang nantinya dibangun untuk fasilitas umum seperti jalan, infrastruktur, rumah sakit, kantor pemerintah, dan sebagainya. Lembaga ini jika memang dilaksanakan sebagaimana mestinya akan mengurangi perkara keberatan nilai ganti rugi tanah untuk kepentingan umum (konsinyasi) di Pengadilan. Adanya Bank Tanah maka akan terwujud prinsip efisiensi dalam perolehan tanah untuk kepentingan umum karena tanpa mengikutsertakan pengadilan yang pada umumnya terjadi proses keberatan dan pembayaran uang ganti rugi/ konsinyasi. $^{2}$

Menurut Menteri Agraria dan Tata Ruang/Kepala Badan Pertanahan Nasional (selanjutnya disebut Menteri ATR/BPN) ${ }^{3}$, Kementerian ATR/ BPN berfungsi sebagai regulator dan manager. Selama ini fungsi

\footnotetext{
2 Mekanisme secara rinci terkait pengadaan tanah untuk kepentingan umum bisa di cermati di dalam Undang-Undang Nomor 2 tahun 2012 tentang Pengadaan Tanah untuk Kepentingan Umum

3 "Penjelasan Menteri ATR/BPN Soal Bank Tanah dalam UU Cipta Kerja" diakses melalui https://www.hukumonline.com/berita/baca/lt5f8 e8f954808a/penjelasan-menteri-atr-bpn-soalbank-tanah-dalam-uu-ciptakerja/\#: :text=Menteri\%20Agraria\%20dan\%20 Tata\%20Ruang,salah\%20satunya\%20mengen ai\%20Bank\%20Tanah. diakses tanggal 31 Oktober 2020 pukul 19.00 WIB
} 
manager tidak berjalan karena tidak memiliki tanah yang bisa digunakan untuk kepentingan umum. Bank Tanah sangat dibutuhkan dan tujuannya, antara lain untuk memfasilitasi investasi, kepentingan umum seperti taman, perumahan rakyat, dan reforma agraria.

Setelah diundangkannya UndangUndang Nomor 5 tahun 1960 tentang Peraturan Dasar Pokok-Pokok Agraria (selanjutnya disebut UUPA), Ketetapan MPR Nomor IX/MPR/2001 tentang Pembaruan Agraria dan Pengelolaan Sumber Daya Alam (Tap MPR No. IX/2001) belum terbit produk legislasi dan regulasi yang secara khusus mengoperasionalkan agenda-agenda dan program reforma agraria. ${ }^{4}$

Negara melalui lembaga pemerintah atau lembaga independen yang ditunjuk oleh pemerintah berwenang melakukan akuisisi tanah terlantar, mengelola dan mengatur sementara waktu, mendistrbusikan untuk kepentingan umum. Hal tersebut merupakan suatu kebijakan pertanahan yang disebut Bank Tanah. $^{5}$ Menurut definisi Bank Tanah

\footnotetext{
${ }^{4}$ Konsorsium Pembaruan Agraria, Pandangan dan usulan terhadap RUU Pertanahan, (Jakarta: Konsorsium Pembaruan Agraria, 2017), hlm. 10.

5 Fatimah Al Zahra, Konstruksi Hukum Pengaturan Bank Tanah Untuk Mewujudkan Pengelolaan Aset Tanah Negara Berkeadilan,
}

merupakan lembaga yang melakukan fungsi penataan terhadap tanah. Fungsi penataan ini sangat luas cakupannya seperti perencanaan, perolehan, pengadaan, pengelolaan, pemanfaatan, dan distribusi tanah sebagaimana diatur didalam UU Cipta Kerja.

Konsep Bank Tanah sebenarnya telah hadir di Indonesia bagian ujung barat yaitu di Aceh yang dikenal dengan lembaga Baitul Mal dan di pulau Sulawesi yaitu Kota Makassar. Pengelolaan tanah terlantar oleh Baitul Mal dengan menggunakan konsep Bank Tanah dan ihya' al-mawat. Baitul Mal bertindak sebagai pengelola harta agama menurut syari'at Islam dapat menentukan status tanah terlantar dan memperuntukkannya pada masyarakat untuk dapat diberdayakan/ dihidupkan /dikelola sebagaimana mestinya dengan tujuan pengembangan kesejahteraan masyarakat sendiri. Disatu sisi, pendayagunaan tanah terlantar kepada masyarakat dapat diberikan dengan status hak sewa maupun hak lainnya atas tanah menurut ketentuan yang berlaku. ${ }^{6}$

Jurnal Arena Hukum Volume 10 Nomor 3 Desember 2017, hlm. 364.

6 Zaki Ulya, Espaktasi Pengelolaan Tanah Terlantar Oleh Baitul Mal Dalam Peningkatan Kesejahteraan Masyarakat", Jurnal Hukum \& Pembangunan Volume 46 No. 4 tahun 2016, HIm. 518. 
Salah satu terobosan untuk mengatasi kompleksitas masalah pengadaan tanah untuk kepentingan pembangunan adalah penerapan bank tanah yang berfungsi sebagai penghimpun tanah, pengaman tanah guna mengamankan penyediaan dan peruntukan serta pemanfaatan tanah sesuai rencana tata ruang yang sudah disahkan. ${ }^{7}$

Kegiatan bank tanah di bidang permukiman rakyat sebagai cikal bakal berdirinya lembaga bank tanah sudah dilaksanakan oleh Pemerintah Kota Makassar. Hal ini terlihat dalam peremajaan kawasan kumuh di Kecamatan Mariso dengan menggunakan tanah seluas 1,2 hektare yang merupakan aset Pemerintah Kota Makassar. ${ }^{8}$ Indonesia yang mengenal asas otonomi daerah memberikan kesempatan kepada pemerintah daerah untuk berinovasi guna melaksanakan fungsi tata kelola pemerintah. Manfaat nyata keberadaan asas ini ternyata dinikmati oleh warga Aceh dan Kota Makassar.

Dari penjelasan-penjelasan tersebut diatas, ada dua isu hukum yang akan dikaji

\footnotetext{
7 Hairani Mochtar, Keberadaan Bank Tanah Dalam Pengadaan Tanah Untuk Pembangunan, Jurnal Cakrawala Hukum, Vol.18, No.2 Desember 2013, HIm. 134.

8 Herni Amir, Kegiatan Bank Tanah Sebagai Bentuk Penyediaan Tanah Untuk Permukiman Rakyat,Analisis, Juni 2014, Vol.3 No.1, hlm. 35.
}

dalam penulisan artikel ini yaitu pertama urgensi pendirian bank tanah menurut Undang-Undang Cipta dan yang kedua Peran serta fungsi Bank Tanah sebagai lembaga pengelola tanah.

\section{B. Metode Penelitian}

Bentuk penelitian ini adalah yuridis normatif, yaitu dengan menelaah norma hukum tertulis langsung dengan pokok permasalahan yang menjadi pembahasan dalam penelitian ini. ${ }^{9}$ Data yang digunakan dalam penelitian ini, yaitu data sekunder yang tidak diperoleh langsung dari lapangan melainkan melalui proses mencari bahan-bahan kepustakaan, dan berupa bahan hukum sekunder berupa teori-teori yang diambil dari berbagai karya pustaka, UUD Negara Republik Indonesia 1945 serta Peraturan PerundangUndangan.

Peneliti menggunakan alat pengumpulan data berupa studi dokumen dan teori serta peraturan-peraturan yang ada. Metode analisis data yang digunakan dalam mengolah data yang berkaitan dengan penelitian ini adalah metode kualitatif karena pengolahan data tidak dilakukan dengan mengukur data sekunder terkait, tetapi menganalisis secara deskriptif data tersebut. Pada pendekatan

\footnotetext{
9 Soerjono Soekanto, Pengantar Penelitian Hukum, (Jakarta: UI-Press, 1986), hal. 10.
} 
kualitatif, tata cara penelitian menghasilkan data deskriptif analitis.

\section{Pembahasan}

Status hukum Bank Tanah di dalam Undang-Undang Cipta Kerja disebut sebagai badan khusus yang mengelola tanah. Pembentuk undang-undang belum menjelaskan secara tegas bentuk hukum Bank Tanah apakah sebagai Badan Usaha Milik Negara/ BUMN, lembaga negara, Badan Layanan Umum/ BLU, atau bentuk yang lain. Status ini sangat penting karena berkaitan dengan pelaksanaan tugas dan wewenang sehari-hari, status pekerja /karyawan, dan perlindungan hukum pihak ketiga.

Pembentukan Bank Tanah berdasarkan UU Cipta Kerja, namun ketentuan lebih lanjut akan diatur di dalam Peraturan Pemerintah. Bentuk hukum ini akan berpengaruh terhadap jenis subjek hukum Bank Tanah dalam penyelenggaraan fungsi dan perannya. Jika sebagai subjek hukum maka ia dapat melakukan perbuatan hukum dengan pihak ketiga sedangkan jika bukan subjek hukum maka ia sebagai bagian unit kerja dari suatu lembaga pemerintahan tertentu. Bentuk pertanggungjawaban Bank Tanah juga belum diatur, bertanggungjawab kepada Presiden atau tidak.
Sedikitnya terdapat 4 isu penting terkait pendirian Bank Tanah sesuai UU Cipta Kerja menurut Maria SW Sumardjono. ${ }^{10}$ Empat isu tersebut yaitu pembentukan Badan Bank Tanah setidaknya belum jelas yakni filosofi, landasan hukum, dan prinsip dasar/asasasasnya, urgensi pembentukannya, asal tanah, dan pihak yang paling diuntungkan dengan keberadaan Badan.

Sekilas tampaknya pembuat undangundang mendahulukan pendirian dan ketentuan umum terlebih dahulu terhadap Bank Tanah. Pendiriannya pun juga diikutsertakan kedalam suatu UndangUndang Omnibus Law yang memuat beraneka ragam Undang-Undang. Menurut penulis inisiatif Pemerintah ini menandakan bahwa kehadiran Bank Tanah sudah mendesak.

Bank Tanah bukan lembaga yang berorientasi pada keuntungan (non profit), undang-undang menghendaki keuntungan sesuai dengan prisip dalam kerjasamaa pemerintah yang objeknya barang milik negara/barang milik daerah. Hal ini tercermin dari Pasal 129 ayat (2) dimana Hak Pengelolaan (HPL) Bank Tanah dapat diberikan Hak Guna usaha/ HGU, Hak

\footnotetext{
${ }^{10}$ Maria SW Sumardjono, Agenda yang Belum Selesai:Refleksi atas Berbagai Kebijakan Pertanahan, (Yogyakarta: Fakultas Hukum Universitas Gadjah Mada, 2020), hlm.97.
} 
Guna Bangunan/ HGB, atau Hak Pakai yang secara yuridis wajib didasarkan perjanjian yang dibuat Bank Tanah dengan mitranya/ pihak ketiga. Konstruksi hukum ini tunduk terhadap hukum pengelolaan barang milik negara/daerah. Selanjutnya akan dibuat suatu perjanjian seperti Perjanjian Penggunaan Tanah sebagaimana diatur didalam Pasal 4 ayat (2) Peraturan Meteri Negara Agraria/ Kepala Badan Pertanahan Nasional Nomor 9 Tahun 1999 Tentang Tata Cara Pemberian Dan Pembatalan Hak Atas Tanah Negara Dan Hak Pengelolaan

Perjanjian Penggunaan Tanah tunduk terhadap PMA, selain itu secara teori tunduk terhadap ketentuan didalam Kitab Undang-Undang Hukum Perdata (KUHPerdata). Ketetuan didalam KUHPerdata tersebut diatur didalam Pasal 1320 yang terdiri dari 4 unsur yakni kesepakatan, kecakapan, hal tertentu dan sebab yang halal. ${ }^{11}$

Dari banyaknya kecaman dan pertentangan terhadap UU Cipta Kerja, ada sisi positif diantaranya lahirnya pengaturan Hak Pengelolaan (selanjutnya disebut HPL) sebagaimana Pasal 136. Sebelumnya HPL tidak diatur didalam UUPA meskipun kata dan makna

11 Nizam Zakka Arrizal, La Validité De La Procuration De Vendre Basé Sur La Décision De Justice, Jurnal Legal Standing Vol.4 No.1, Maret 2020, HIm.79.
"Pengelolaan" dapat ditemukan di dalam romawi II angka 2 penjelasan umum UUPA. Akhirnya ada peraturan setingkat Undang-Undang yang mengatur HPL meskipun di sisi lain ada yang beranggapan bahwa HPL bukan hak atas tanah karena tidak diatur di dalam Pasal 4 dan Pasal 16 UUPA.

HPL merupakan hak menguasai dari negara yang kewenangan pelaksanaannya sebagian dilimpahkan kepada pemegang haknya. HPL sebelumnya diatur diantaranya didalam Undang-Undang Nomor 16 tahun 1985 tentang Rumah Susun, Undang-Undang Nomor 21 tentang 1997 tentang Bea perolehan Hak atas Tanah dan Bangunan, Peraturan Pemerintah Nomor 40 tahun 1996 tentang Hak Guna Usaha, Hak Guna Bangunanm dan Hak Pakai atas Tanah, Peraturan Pemerintah Nomor 24 tahun 1997 tentang Pendaftaran Tanah, dan Peraturan Menteri Agraria No. 9 tahun 1999. UU No 16 tahun 1985 tentang Rumah Susun dan UU No. 21 tahun 1997 tentang Bea Perolehan Hak Atas Tanah dan Bangunan tidak mendefinisikan secara tegas HPL itu apa karena hanya menyinggung keberadaannya secara singkat. Di dalam PMA No. 9 tahun 1999 disebutkan beberapa instansi yang dapat diberikan HPL.

Pengkategorian lembaga Bank Tanah sangat fundamental mengingat 
setiap jenis lembaga mempunyai dasar hukum masing-masing yang harus dipatuhi seperti BUMN tunduk terhadap peraturan menteri BUMN, Pemerintah Daerah tunduk terhadap Peraturan Menteri Dalam Negeri, BLU tunduk terhadap Peraturan Menteri Keuangan. Hal ini mengingat kekayaan Bank Tanah merupakan kekayaan Negara yang dipisahkan sehingga dalam mengelolanya harus penuh hati-hati dan waspada agar pihak-pihak yang andil didalamnya tidak merugikan keuangan negara yang dipisahkan tersebut.

Dua hal yang perlu menjadi perhatian terhadap HPL Bank Tanah yang pertama adalah Perjanjian Penggunaan Tanah tersebut diatas dan bentuk pemanfaatannya. Bentuk pemanfaatannya beraneka ragam yang dapat menjadi pilihan/alternatif bagi Bank Tanah beserta mitranya diantaranya Sewa, Pinjam Pakai, Kerja Sama Pemanfaatan, Bangun Guna Serah/ Bangun Serah Guna, Kerja Sama Penyediaan Infrastruktur.

Segala hal menyangkut keuangan merupakan isu yang sensitif terlebih berkaitan dengan keuangan negara. Pihak yang mengelola keuangan negara ini jangan sampai dirugikan sehingga pada akhirnya akan menimbulkan kerugian keuangan negara.

Di beberapa peraturan perundangundangan yang berkaitan dengan pengelolaan barang milik negara/daerah mewajibkan pengelola HPL untuk menetapkan penerimaan negara ke dalam perjanjian. Dalam hal tersebut terdapat pengaturan utama di dalam Peraturan Pemerintah Nomor Nomor 27 Tahun 2014 tentang Pengelolaan Barang Milik Negara/Daerah yang melahirkan beberapa peraturan pelaksana diantaranya Peraturan Menteri Keuangan Republik Indonesia Nomor 78/PMK.06/2014 Tentang Tata Cara Pelaksanaan Pemanfaatan Barang Milik Negara (selanjutnya disebut Permenkeu 78/2014) dan Peraturan Menteri Dalam Negeri Nomor 19 tahun 2016 tentang Pedoman Pengelolaan Barang Milik Daerah. Nuansa sensitif tersebut tercermin dari pengaturan kontribusi tetap dan pembagian keuntungan yang wajib diatur didalam perjanjian kerja sama pemanfaatan. Hal tersebut diamanatkan oleh Permenkeu $78 / 2014$. Oleh sebabnya perlu adanya kajian tersendiri terhadap pengelolaan aset milik Bank Tanah yang merupakan kekayaan negara yanng dipisahkan.

Peruntukan HPL Bank Tanah dibagi dua yaitu untuk kepentingan ekonomi berkeadilan dan untuk investasi. Bank Tanah harus memiliki skala prioritas untuk kepentingan siapa HPL Bank Tanah nantinya. Jika berorientasi untuk kepentingan yang pertama maka sudah 
seharusnya ia menyediakan tanah untuk masyarakat Indonesia yang mempunyai hubungan kekal dan abadi karena tanah sebagai karunia Tuhan Yang Maha Esa. Jika untuk kepentingan yang kedua maka tanah HPL Bank Tanah dapat bekerjasama dengan pemilik manfaatnya yaitu masyarakat Indonesia sebagaimana dicitacitakan UUPA dan Pasal 33 ayat (3) UUDNRI 1945.

Bank Tanah merupakan instansi tambahan yang dapat diberikan HPL selain instansi pemerintah, BUMN, BUMD, PT. Persero, Badan Otorita, atau Badan-badan hukum Pemerintah lainnya. Dari karakter penerima HPL ini semuanya merupakan lembaga pemerintah atau perusahaan milik pemerintah (BUMN/BUMD) sehingga bank tanah merupakan bagian dari fungsi pemerintahan.

Bank Tanah dapat dikatakan sebagai lembaga di bidang eksekutif dilihat dari Komite sebagai salah satu organ Bank Tanah. Komite terdiri dari ketua yaitu menteri di bidang pertanahan dan anggota yaitu menteri di bidang lain yang semuanya ditetapkan oleh Keputusan Presiden. Dari ketentuan ini, maka seorang menteri ATR/kepala BPN berkedudukan tiga jabatan sekaligus, ia sebagai menteri agraria dan tata ruang, sebagai kepala Badan Pertanahan Nasional, dan sebagai Ketua Komite Bank Tanah.
Peruntukan tanah yang dikelola oleh Bank Tanah ada 2 yaitu dalam rangka ekonomi berkeadilan dan dalam rangka mendukung investasi. Dalam rangka ekonomi berkeadilan, Bank Tanah menjamin ketersediaan tanah minimal $30 \%$ (tiga puluh) persen guna reforma agrarian, sedangkan dalam rangka mendukung investasi, pemegang HPL Bank Tanah diberikan beberapa kewenangan. Kedua macam peruntukan ini bertolak belakang karena yang satu ada di pihak bangsa Indonesia sebagai pemilik bumi, air, dan luar angkasa, sedangkan yang lain bisa dikatakan pro investor yang bisa datang dari tuan rumah atau bisa juga tamu dari luar.

Inkonsistensi peruntukan tersebut menunjukkan bahwa pembuat kebijakan mengesampingkan eksistensi Pasal 33 ayat (3) Undang-Undang Dasar Negara Republik Indonesia 1945 yang mengamanatkan bumi dan air dan kekayaan alam yang dipergunakan untuk sebesar-besar kemakmuran rakyat. Seyogyanya pembuat undang-undang memilih salah satu peruntukan saja asalkan muara akhirnya yaitu sebesar-besarnya untuk kemakmuran rakyat Indonesia. Hal ini dikarenakan kepentingan investasi bernuansa asing dan hanya untuk kaum elit. Padahal, kehadiran Bank Tanah diharapkan dapat menyediakan tanah bagi 
masyarakat yang belum mendapatkan tanah untuk hunian atau untuk kepentingan umum.

Ketentuan bahwa Bank Tanah dapat mengelola aset secara mandiri dengan antara lain melakukan kerjasama dengan pihak ketiga berpotensi untuk diprioritaskan ketimbang melaksanakan tugas dan fungsi utamanya untuk menyediakan dan mendistribusikan tanah agar terjamin ketersediaan tanah untuk kepentingan umum, kepentingan sosial, dan lain-lain. Berdasarkan tugas dan fungsi utamanya tidak tepat jika Bank Tanah menjadi subjek HPL. ${ }^{12}$

Menurut penulis jika tujuan didirikannya Bank Tanah adalah untuk menyediakan tanah maka harus ditegaskan dalam Undang-Undang atau Peraturan Pemerintah yang nanti dibuat, bahwa Bank Tanah didirikan untuk menyediakan tanah bagi masyarakat. Hal ini agar apa yang diharapkan pemerintah sesuai dengan produk hukumnya supaya "grand design" didirikannya Bank Tanah itu jelas. Makna jelas yang dimaksud adalah mudah dilaksanakan bagi siapapun yang ada didalam organ Bank Tanah, supaya niat atau tindakan yang tidak sesuai dengan tujuan tersebut dapat dihindari.

\footnotetext{
${ }^{12} \mathrm{lbid}, \mathrm{hlm} .78$.
}

Kebutuhan masyarakat akan kepemilikan tanah sangat besar. Di atas tanah dapat dibangun rumah atau tempat tinggal dengan sebutan lain untuk kepentingan pribadi yang berdasarkan jenisnya berstatus hak milik. Tanah juga dapat digunakan untuk kepentingan usaha atau bisnis diantaranya pertanian, perikanan, peternakan dengan dasar Hak Guna Usaha atau non pertanian dengan dasar Hak Guna Bangunan atau Hak Pakai.

Objek yang dapat dikelola Bank Tanah sangat terbatas. Berdasarkan Pasal 129 ayat (1), tanah yang dikelola badan bank tanah diberikan hak pengelolaan. Wewenang Bank Tanah ini menurut penulis secara yuridis telah diatur di peraturan tersendiri. Dalam Peraturan Pemerintah Nomor 40 Tahun 1996 Tentang Hak Guna Usaha, Hak Guna Bangunan Dan Hak Pakai Atas Tanah (selanjutnya disebut PP No. 40 tahun 1996) telah diatur bahwa Menteri mengatur dan menentukan peruntukan Hak Pengelolaan. PP No. 40 tahun 1996 mengatur bahwa diatas tanah HPL dapat diberikan HGB atau Hak Pakai.

Selanjutnya di dalam Peraturan Meteri Negara Agraria/ Kepala Badan Pertanahan Nasional Nomor 9 Tahun 1999 tentang Tata Cara Pemberian Dan Pembatalan Hak Atas Tanah Negara Dan Hak Pengelolaan (selanjutnya disebut PMA 9/1999) terdapat 
lembaga khusus yaitu Panitia Pemeriksa Tanah yang bertugas melaksanakan pemeriksa tanah dalam rangka penyelesaian permohonan untuk memperoleh Hak Milik, Hak Guna Usaha, Hak Guna Bangunan, Hak Pakai atas tanah Negara termasuk Hak Pengelolaan.

Jika ketentuan Bank Tanah di dalam UU Cipta Kerja tetap diberlakukan maka akan ada Overlaping atau tumpang tindih kewenangan. Kewenangan Bank Tanah akan mengeleminasi kewenangan Menteri / kepala kantor wilayah / kepala kantor pertanahan. Secara yuridis, menteri melalui kepala kantor wilayah atau kepala kantor pertanahan yang akan menetapkan dan memberikan izin kepada seseorang untuk menikmati HPL. Hal ini sebagaimana diatur dalam PMA 9/1999 dan PP 40/1996.

Pengaturan pemberian Hak Milik atas tanah rumah tinggal juga diatur lebih spesifik didalam Keputusan Meteri Negara Agraria/ Kepala Badan Pertanahan Nasional Nomor 6 Tahun 1998 tentang Pemberian Hak Milik atas tanah untuk rumah tinggal. Pasal 2 menjelaskan bahwa permohonan pendaftaran hak milik diajukan kepada kepala kantor pertanahan kabupaten/kotamadya.

Impian masyarakat untuk memiliki tanah hak milik dengan adanya Bank Tanah akan sulit diraih mengingat hak milik bukan objek yang dapat dimintakan ke Bank Tanah atau hak atas tanah yang dapat diberikan diatas tanah HPL Bank Tanah. Di atas tanah HPL Bank Tanah hanya dapat diberikan $\mathrm{HGB}$, HGU, atau Hak Pakai saja. Dari ketentuan ini nampak bahwa tujuan didirikannya Bank Tanah tidak lain adalah untuk pemberian hak atas tanah demi kepentingan bisnis, bukan untuk pemukiman/ tempat tinggal. Selain itu, meskipun di atas tanah HGB atau Hak Pakai dapat didirikan suatu tempat tinggal namun kenikmatannya tidak lebih baik dari tanah hak milik misalnya perumahan atau rumah susun karena hak milik memiliki keistimewaan dibanding hak atas tanah yang lain.

Dalam disiplin ilmu hukum dikenal suatu asas Lex superior derogat legi inferior yang bermakna norma hukum yang lebih tinggi tingkatannya akan mengesampingkan norma hukum yang berada dibawahnya. Jika asas ini diterapkan dalam UU Cipta kerja dan peraturan perundang-undangan yang lainnya maka yang berlaku adalah UU Cipta Kerja sehingga menteri melalui kepala kantor wilayah atau kepala kantor pertanahan akan kehilangan kewenangannya karena sudah digantikan oleh Bank Tanah. Tugas yang digantikan adalah terkait pengurusan HPL. 
Struktur organisasi Bank Tanah terdiri dari 3 organ yaitu Komite, Dewan Pengawas, dan Badan Pelaksana. Pengaturan lebih lanjut terkait tiga organ ini akan ditetapkan dengan Peraturan Presiden. Dari ketiga organ ini, Komite merupakan organ yang mempunyai posisi paling kuat karena diisi oleh para menteri atau kepala lembaga serta dapat menetapkan Badan Pelaksana yang terdiri dari kepala dan deputi.

Keberadaan Bank Tanah ini akan menjadi tantangan bagi pemerintah yang menginisiasi berdirinya lembaga pengelolaan tanah tesebut. Tantangan Bank Tanah diantaranya :

a) Kepentingan mana yang akan didahulukan antara kepentingan investasi atau kepentingan ekonomi berkeadilan dalam penyediaan dan distribusi tanah;

b) Adanya tumpang tindih kewenangan antara Bank tanah dan Menteri di bidang pertanahan atau Kepala Kantor Pertanahan/ Kepala Kantor Wilayah Pertanahan;

c) Harapan untuk mengurangi beban perkara di Pengadilan akibat Konsinyasi (keberatan ganti kerugian) pengadaan tanah untuk kepentingan umum harus maksimal;

\section{Kesimpulan}

Kehadiran Bank tanah sangat dibutuhkan oleh masyarakat dan pemerintah dalam pengelolaan dan penataan tanah untuk kepentingan umum dan tempat tinggal. Wewenang Bank Tanah belum diatur secara tegas didalam UU Cipta Kerja karena secara umum wewenang terkait pertanahan ada di tangan Menteri yang membidangi pertanahan atau pemegang hak atas tanah yang bersangkutan. Peran dan fungsi Bank tanah adalah lembaga yang mengelola tanah dengan melaksanakan perencanaan, perolehan, pengadaan, pengelolaan, pemanfaatan, dan pendistribusian tanah. Perlu adanya beberapa peraturan pelaksana UU Cipta Kerja yang khusus tentang Bank Tanah untuk segera disahkan agar pelaksanaan fungsi dan peran Bank Tanah bisa segera dirasakan masyarakat. Pemerintah sekiranya dapat membuat prioritas utama diantara dua pilihan yaitu dalam rangka ekonomi berkeadilan dan dalam rangka mendukung investasi terkait peruntukan tanah HPL yang dikelola Bank Tanah.

\section{Daftar Pustaka}

\section{Buku}

Agtas, Supratman Andi. Laporan Badan Legislasi DPR RI Dalam Rangka Pembicaraan Tingkat II / 
Pengambilan Keputusan Hasil Pembahasan RUU tentang cipta kerja yang telah diselesaikan oleh Badan Legislasi Dalam Rapat Paripurna DPR RI. 6 Oktober 2020. hal. 4.

Soekanto, Soerjono. Pengantar Penelitian Hukum. Jakarta: UI-Press. 1986.

Sumardjono, Maria SW. Agenda yang Belum Selesai : Refleksi atas Berbagai Kebijakan Pertanahan. Yogyakarta: Fakultas Hukum Universitas Gadjah Mada.2020.

\section{Website}

"Penjelasan Menteri ATR/BPN Soal Bank Tanah dalam UU Cipta Kerja" sumber dari website https://www.hukumonline.com/berit a/baca/lt5f8e8f954808a/penjelasanmenteri-atr-bpn-soal-bank-tanahdalam-uu-ciptakerja/\#: :text=Menteri\%20Agraria\% 20dan\%20Tata\%20Ruang,salah\%20 satunya \%20mengenai\%20Bank\%20 Tanah, diakses tanggal 31 Oktober 2020 pukul 19.00 WIB

\section{Karya Ilmiah}

Herni Amir, Kegiatan Bank Tanah Sebagai Bentuk Penyediaan Tanah Untuk Permukiman Rakyat. Jurnal Analisis Volume 3 No. 1. Juni 2014

Konsorsium Pembaruan Agraria. Pandangan dan usulan terhadap RUU Pertanahan. Jakarta: Konsorsium Pembaruan Agraria. 2017.

Hairani Mochtar, Keberadaan Bank Tanah Dalam Pengadaan Tanah Untuk Pembangunan. Jurnal Cakrawala Hukum, Volume 18, No.2 Desember 2013.
Nizam Zakka Arrizal, La Validité De La Procuration De Vendre Basé Sur La Décision De Justice. Jurnal Legal Standing Vol.4 No.1, Maret 2020.

Zaki Ulya, Espaktasi Pengelolaan Tanah Terlantar Oleh Baitul Mal Dalam Peningkatan Kesejahteraan Masyarakat". Jurnal Hukum \& Pembangunan, Volume 46 No. 4 tahun 2016.

Fatimah Al Zahra, Konstruksi Hukum Pengaturan Bank Tanah Untuk Mewujudkan Pengelolaan Aset Tanah Negara Berkeadilan. Jurnal Arena Hukum Volume 10 Nomor 3 Desember 2017

\section{Peraturan Perundang - Undangan}

Undang-Undang Dasar Republik Indonesia Tahun 1945

Undang-Undang Republik Indonesia No. 5 Tahun 1960 Tentang Peraturan Dasar Pokok-Pokok Agraria

Undang-Undang Nomor 16 tahun 1985 tentang Rumah Susun

Undang-Undang Nomor 21 tentang 1997 tentang Bea Perolehan Hak Atas Tanah dan Bangunan

Peraturan Pemerintah Nomor 40 tahun 1996 tentang Hak Guna Usaha, Hak Guna Bangunan dan Hak Pakai atas Tanah

Peraturan Pemerintah Nomor 24 tahun 1997 tentang Pendaftaran Tanah

Peraturan Meteri Negara Agraria/ Kepala Badan Pertanahan Nasional Nomor 9 Tahun 1999 Tentang Tata Cara Pemberian Dan Pembatalan Hak Atas Tanah Negara Dan Hak Pengelolaan 